\title{
The Agreement Between Blood Pool - Delayed Bone Scintigraphy and Tc-99m Human Immunoglobulin G (HIG) Scintigraphy in the Determination of the Presence and Severity of Inflammatory Arthritis
}

\author{
Inflamatuvar Artritlerin Varlı̆̆ı ve Şiddetinin Belirlenmesinde Kan Havuzu-Geç Dönem \\ Kemik Sintigrafisi ile Tc-99m Human Immünoglobulin G (HIG) Sintigrafileri Arasındaki Uyum
}

\author{
Gulizar Kacarl, Cahit Kacar2, Firat Gungorl \\ IAkdeniz University School of Medicine, Department of Nuclear Medicine, Antalya, Turkey \\ 2Akdeniz University School of Medicine, Department of Physical Medicine and Rehabilitation, Antalya, Turkey
}

\begin{abstract}
Objective: In this study, it was aimed to investigate the agreement between early phase of bone scintigraphy - human immunoglobulin scintigraphy (EPBS-HIG) and late phase bone scintigraphy - HIG (LPBS-HIG) in the determination of the presence and also the severity of inflammatory arthritis.

Material and Methods: Twenty-eight patients ( 23 female, 5 male; between 19 to 80 years of age) with inflammatory arthritis were included in the study. Tc-99m HIG and blood pool/late phase bone scintigraphies were performed in all patients. In scintigraphic examinations, the joints were scored with the degree of accumulation of the radiopharmaceutical by the semiquantitative analysis ( 0 =Background activity, 1=Faint uptake, 2=Moderate uptake, 3=Marked uptake) which is called as visually active joint score as severity index of the disease. To estimate the agreement between EPBS - HIG and LPBS - HIG in the determination of the presence and severity of inflammatory arthritis, $2 \times 2$ kappa coefficients were calculated.

Results: Our results showed good agreement between EPBS - HIG for the presence of inflammation (kappa: 0.72 ) but not for the severity of the disease (kappa: 0.29), poor agreement between LPBS - HIG for both the presence (kappa: 0.51) and severity (kappa: 0.01) of inflammatory arthritis.

Conclusion: The blood pool scintigraphy could be used in the investigation of the presence of inflammatory arthritis because the good agreement with HIG and the lower cost but not for the severity of the disease. (MIRT 201 1;20:45-51)

Key words: Rheumatoid Arthritis, Reactive Arthritis, Technetium 99m HIG
\end{abstract}

\section{Özet}

Amaç: Bu çalıșmada, inflamatuvar artritlerin varlığı ve șiddetinin belirlenmesinde erken dönem kemik sintigrafisi - human immünoglobulin (EDKS - HIG) ve geç dönem kemik sintigrafisi - HIG (GDKS - HIG) arasındaki uyumun incelenmesi amaçlanmıștır.

Gereç ve Yöntemler: Çalıșmaya inflamatuvar artriti olan 28 hasta (23 erkek, 5 kadın; yas aralığı 19-80) dahil edilmiștir. Tüm hastalara Tc-99m HIG ve kan havuzu/geç dönem kemik sintigrafisi tetkikleri gerçekleștirilmiștir. Eklemler, sintigrafik çalıșmalarda "görsel aktif

Address for Correspondence: Firat Gungor MD, Akdeniz University School of Medicine, Department of Nuclear Medicine, Antalya, Turkey Fax: : +90 2422496476 E-mail: fgungor@akdeniz.edu.tr Received: 23.06.2011 Accepted: 09.09.2011 
eklem" diye isimlendirilen ve hastalığın șiddet göstergesi olarak radyofarmasötik tutulum derecesine göre semikantitatif skorlanmıștır $10=$ zemin aktivite, $1=$ hafif tutulum, $2=$ orta derecede tutulum, $3=$ belirgin tutulum). İnflamatuvar artritin varlığı ve șiddetinin belirlenmesinde EDKS - HIG ve GDKS - HIG arasındaki uyumu saptamak için 2x2 kappa katsayıları hesaplanmıștır.

Bulgular: Sonuçlarımız, EDKS - HIG arasında inflamasyonun saptanmasında iyi uyum olduğunu (kappa: 0.72), ancak hastalık șiddeti için iyi uyum olmadığıı (kappa: 0.29), GDKS - HIG'de ise hem inflamatuvar artritin saptanmasında (kappa: 0.51) hem de siddetinin belirlenmesinde (kapa: 0.01) kötü bir uyum olduğunu göstermiștir.

Sonuç: Kan havuzu sintigrafisi, HIG ile iyi uyumu ve daha düșük fiyatlı olması nedeniyle inflamatuvar artritlerin varlığının gösterilmesinde kullanılabilir ancak hastalık siddetinin belirlenmesinde kullanılması uygun değildir. (MIRT 201 1;20:45-51)

Anahtar kelimeler: Romatoid artrit, reaktif artrit, teknesyum 99m HIG

\section{Introduction}

Radiopharmaceuticals have been used for detection of inflammation and to evaluate the activity of the arthritis in several arthritic conditions $(1,2,3,4,5)$. Some radiopharmaceuticals accumulate nonspecifically in arthritic joints because of the increased vascular permeability at the site of inflammation or particular physicochemical properties (6). In inflammatory joint disease, the uptake of diphosphonates in bone is either secondary to increased blood flow to periarticular bone, or is related to new bone formation with diphosphonate absorbed on the surface of hydroxyapatite crystals or is a combination of both factors (1). Bone scintigraphy appeared to be a sensitive method for detecting inflammatory joint disease, however the disadvantage of bone scintigraphy is its' low specificity $(1,7,8,9)$. Other radiopharmaceuticals such as Ga-67 $(10,11)$, radiolabelled leucocytes (12), In-1 11 chloride (13), $99 \mathrm{mTc}$ labelled liposomes (14) were demonstrated to accumulate in inflammed area in arthritis, however these agents have not been used in routine clinical practice (15). Some radiopharmaceuticals were considered as specific targeting agents for inflammation in especially rheumatoid arthritis (RA). Promising results have been reported with radiolabelled CD4, E-selectin antibodies and somatostatin receptor imaging (6). Recently, FDG PET has been used for monitoring response to treatment in RA (16).

HIG scintigraphy has been suggested as a reliable and objective imaging method of joint inflammation. The mechanism of HIG accumulation at the site of inflammation has still to be conclusively determined $(1,6)$. The following hypotheses have been proposed; increased vascular permeability (17), specific trapping of $\lg G$ by receptors for immunoglobulins located on inflammatory cells (18), binding of to extracellular matrix proteins (19) and bacterial affinity (20).

Bone scintigraphy is easy to use and cheaper compare to HIG scintigraphy in routine use. To date, late phase bone scintigraphy (LPBS) has been compared to HIG scintigraphy in inflammatory arthritis. However, there is not enough information about the agreement between early phase of bone scintigraphy (EPBS) and HIG scintigraphy in inflammatory arthritis. In this study, we aimed to investigate the agreement between EPBS-HIG and LPBS-HIG scintigraphy in the determination of the presence and also the severity of inflamatory arthritis.

\section{Materials and Methods}

\section{Subjects}

The study involved 28 patients ( 23 female, 5 male; age between 19 to 80 years) with RA (19 patients) diagnosed according to 1987 American College of Rheumatology (ACR) criteria (21) and reactive arthritis ( $\operatorname{ReA})$ (9 patients). The range of disease duration was 6 month-35 years and 1 month- 1 year in the patients with RA and $\operatorname{ReA}$, respectively. Clinical assessment of arthritis activity was performed with tenderness and swollen of joints.

\section{Scintigraphy}

HIG (Mallinckrodt Diagnostica, Holland) was radiolabelled by Tc $99 \mathrm{~m}$ according to the instructions. Imaging was performed after 4 hours after the iv injection of $555 \mathrm{MBq}$ of the tracer. Whole body scans and anterior spot views of the shoulders, elbows, hands and wrists, hips, knees, ankles and forefeet were acquired at preset times of 5 minutes.

Bone scans were performed by iv injection of $555 \mathrm{MBq}$ Tc $99 \mathrm{~m}$ Medronate two days after HIG scintigraphy. Blood pool and late phase static images were acquired at preset times of 2 and 5 minutes, respectively, at the same areas with HIG scintigraphy. Total blood pool imaging time for each patient was between 10 to 12 minutes.

Toshiba GCA 602 A gamma camera equipped with low energy all purpose collimator was used for all acquisitions.

\section{Scintigraphic Evaluation}

The scintigrams were evaluated by the consensus of two experienced Nuclear Medicine physicians (GK, FG) who were unaware of the patient's clinical status. In scintigraphic examinations, the joints were scored with the degree of accumulation of the radiopharmaceutical by the semiquantitative analysis called "visually active joint score" representing the 
severity index of the disease as follows: $0=$ Background activity (Figure 1), 1=Faint uptake (mild inflammation) (Figure 1), $2=$ Moderate uptake (moderate inflammation) (Figure 2), $3=$ Marked uptake (severe inflammation) (Figure 3).

Forty-four and 46 joints were investigated for each patient in RA and ReA, respectively by HIG, EPBS, and LPBS. These joints were as follows: shoulders (2), elbows (2), wrists (2),

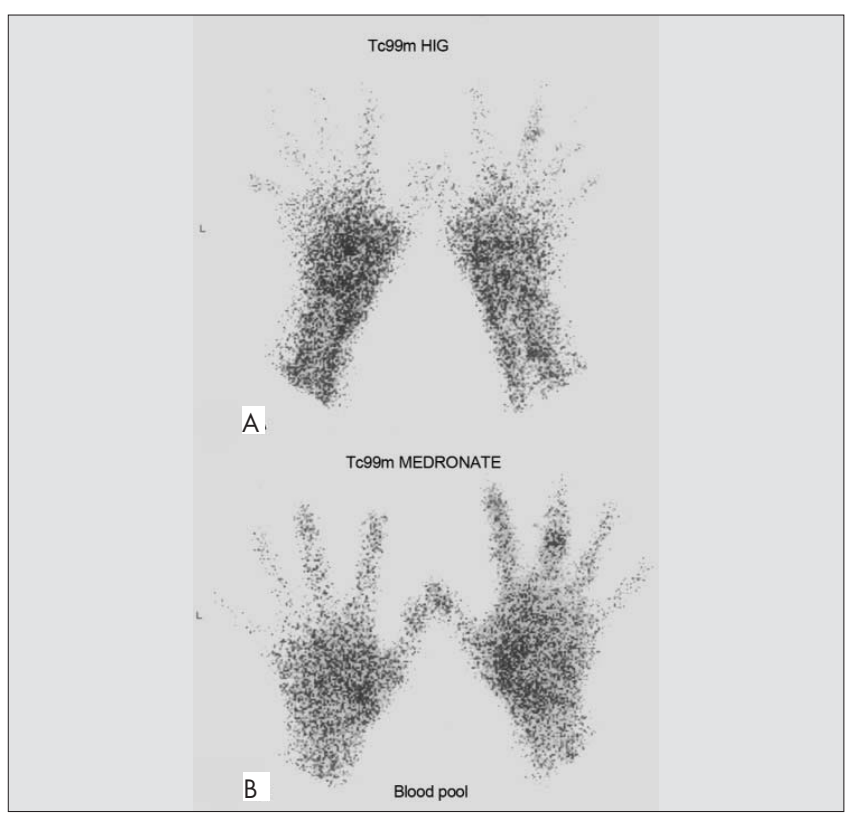

Figure 1. Tc 99m HIG scintigraphy (A) and Tc 99m Medronate blood pool scintigraphy $(B)$ in the same patient

Faint uptake $(V A J S=1)$ in the proximal interphalangeal joint (at 3rd phalanx of the right hand) and normal uptake of radiopharmaceutical at the level of background activity $(V A J S=0)$ for other joints of both hands and wrists in HIG and Medronate blood pool scintigraphy

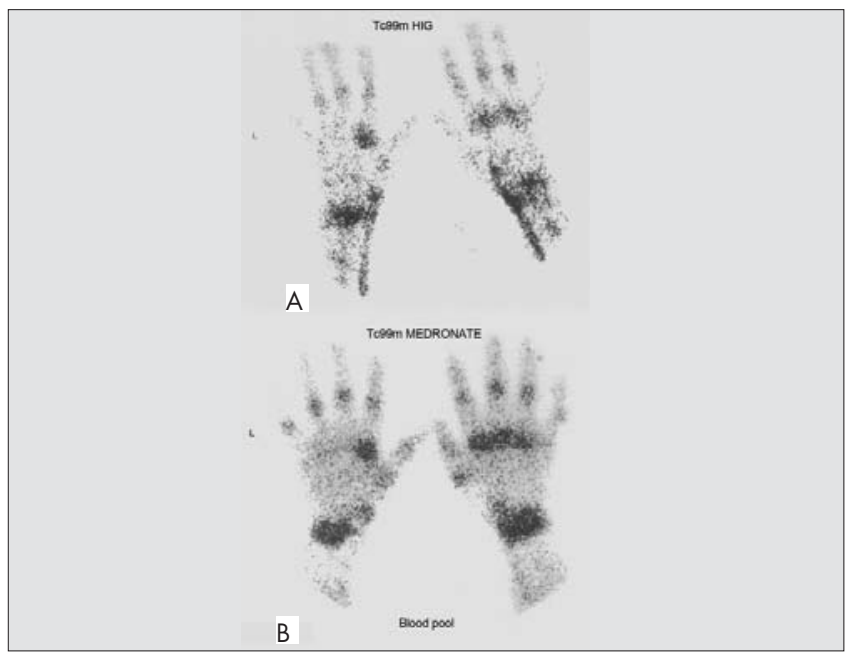

Figure 2. Tc 99m HIG scintigraphy (A) and Tc 99m Medronate blood pool scintigraphy $(B)$ in the same patient

Moderate uptake (VAJS $=2$ ) in both wrists and metacarpophalangeal joints. Faint and moderate uptake in proximal interphalangeal joints by HIG and Medronate blood pool scintigraphy metacarpophalangeal (10), proximal interphalangeal (10), distal interphalangeal (8), hips (2), knees (2), ankles (2), metatarsophalangeal (2) and forefeet (2). Since sacroiliac joint is not a commonly involved joint, it was not evaluated in RA. It was also not possible to score the different metatarsophalangeal and interphalangeal joints of the feet separately, so these joints were taken as a single articular segment.

Before including the study, detailed information was given to all patients and all patients gave informed consent for the study.

\section{Statistical Analysis}

To estimate the agreement between HIG - EPBS and HIG - LPBS in the determination of the presence and severity of inflamatory arthritis, $2 \times 2$ kappa coefficients were calculated (22).

\section{Results}

Clinical characteristics and the sum of VAJS for each patient for HIG, EPBS, and LPBS are shown in Table 1. Even the total number of joints evaluated for all patient was 1250 (44 joints x 19 patients with RA; 46 joints $\times 9$ patients with $\operatorname{ReA}$ ), it was not possible to compare HIG-EPBS and HIG-LPBS with each other for all joints due to the variations in acquisition and technical problems. The number of joints compared with each other in HIG-EPBS and HIG-LPBS were 415 and 473 , respectively.

Tables 2 to 5 show the agreement results between HIG EPBS and HIG - LPBS in the determination of the presence and severity of arthritis.

\section{Discussion}

The availability of an objective and reproducible method to evaluate the activity of the arthritis would be of great value

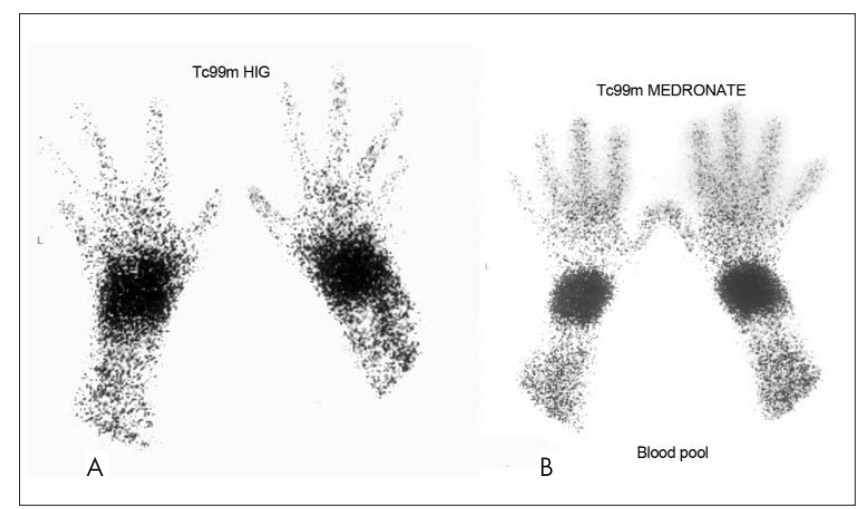

Figure 3. Tc 99m HIG scintigraphy (A) and Tc 99m Medronate blood pool scintigraphy $(B)$ in the same patient

Marked uptake (VAJS=3) in both wrists. Normal uptake in other joints of both hands by HIG and Medronate blood pool scintigraphy 
in management of patients and assessment of therapeutic effects (6). Many of the studies have shown that nonspecific polyclonal human lgG scintigraphy is a useful test for localizing and detecting inflammatory joint activity and inflammation $(23,24,25,26,27,28,29,30)$.
In the literature, LPBS has been compared to HIG scintigraphy in inflammatory arthritis for only in the determination of the presence of inflammatory arthritis $(24,29)$. However, there is not enough information about the agreement between LPBS - HIG scintigraphy in the determination of the severity of dis-

Table 1. Clinical characteristics and the sum of visually active joint scores for HIG, EPBS, and LPBS of each patient

\begin{tabular}{|c|c|c|c|c|c|c|c|c|}
\hline Patient no & Age (year) & Gender & $\begin{array}{c}\text { Disease } \\
\text { duration (year) }\end{array}$ & Diagnosis & NSJ & HIG & EPBS & LPBS \\
\hline 1 & 48 & $\mathrm{~F}$ & 25 & RA & 2 & 17 & 18 & 35 \\
\hline 2 & 50 & $\mathrm{~F}$ & 4 & RA & 3 & 28 & 30 & 40 \\
\hline 3 & 46 & $\mathrm{~F}$ & 3 & RA & 2 & 23 & 19 & 34 \\
\hline 4 & 35 & $\mathrm{~F}$ & 1 & RA & 8 & 16 & 19 & 30 \\
\hline 5 & 45 & $\mathrm{~F}$ & 5 & RA & 0 & 2 & 2 & 36 \\
\hline 6 & 57 & $\mathrm{~F}$ & 5 & RA & 0 & 31 & 25 & 30 \\
\hline 7 & 45 & $\mathrm{~F}$ & 3 & RA & 6 & 15 & 28 & 45 \\
\hline 8 & 57 & $\mathrm{~F}$ & 11 & RA & $\star *$ & 4 & 4 & 24 \\
\hline 9 & 39 & $\mathrm{~F}$ & 1 & RA & 6 & 24 & 16 & 36 \\
\hline 10 & 40 & $\mathrm{~F}$ & 12 & RA & 1 & 13 & ** & 33 \\
\hline 11 & 80 & $\mathrm{~F}$ & 4 & RA & 0 & 16 & 41 & 46 \\
\hline 12 & 54 & $M$ & 0,5 & RA & 0 & 22 & 18 & 31 \\
\hline 13 & 32 & $\mathrm{~F}$ & 8 & RA & 1 & 15 & $\star *$ & 33 \\
\hline 14 & 53 & $\mathrm{~F}$ & 30 & RA & 1 & 25 & 20 & 33 \\
\hline 15 & 30 & $\mathrm{~F}$ & 2 & RA & 0 & 33 & 20 & 39 \\
\hline 16 & 42 & $\mathrm{~F}$ & 14 & RA & 2 & 19 & 21 & 38 \\
\hline 17 & 53 & $\mathrm{~F}$ & 35 & RA & 7 & 26 & 29 & 43 \\
\hline 18 & 46 & $\mathrm{~F}$ & 15 & RA & 2 & 16 & 18 & 36 \\
\hline 19 & 55 & $\mathrm{~F}$ & 5 & RA & 3 & 16 & 13 & 20 \\
\hline 20 & 48 & $\mathrm{~F}$ & 25 & RA & 1 & 7 & 4 & 9 \\
\hline 21 & 46 & $\mathrm{~F}$ & 0,05 & $\operatorname{ReA}$ & 2 & 15 & 13 & 24 \\
\hline 22 & 19 & $M$ & 0,05 & $\operatorname{Re} A$ & 0 & 6 & 4 & 10 \\
\hline 23 & 42 & $M$ & 0,1 & $\operatorname{Re} A$ & 0 & 5 & 5 & 18 \\
\hline 24 & 24 & $\mathrm{~F}$ & 0,1 & $\operatorname{Re} A$ & 1 & 14 & $\star *$ & 15 \\
\hline 25 & 30 & $M$ & 0,5 & $\operatorname{Re} A$ & 0 & 6 & 9 & 35 \\
\hline 26 & 48 & $M$ & 0,5 & $\operatorname{Re} A$ & 1 & 3 & 3 & 3 \\
\hline 27 & 30 & $\mathrm{~F}$ & 1 & $\operatorname{Re} A$ & 1 & 3 & 3 & 6 \\
\hline 28 & 42 & $\mathrm{~F}$ & 0,3 & $\operatorname{ReA}$ & 3 & 14 & 12 & 11 \\
\hline
\end{tabular}

ReA: Reactive Arthritis; RA: Rheumatoid Arthritis; EPBS: Early phase of bone scintigraphy; NSJ: Number of swollen joints; F: Female; M: Male; LPBS: Late phase of bone scintigraphy; VAJS: Visually Active Joint Score;

** EPBS VAJS and NSJ could not be evaluated in patients 10,13,24 and 8, respectively 
ease. In addition, in the literature, the agreement between EPBS - HIG for the determination of the presence and also the severity of the disease are not well known, either. The present study has adressed to clarify this point. Our study showed that there was a good agreement between HIG and EPBS in the

Table 2. The number of positive and negative joints in HIG and EPBS

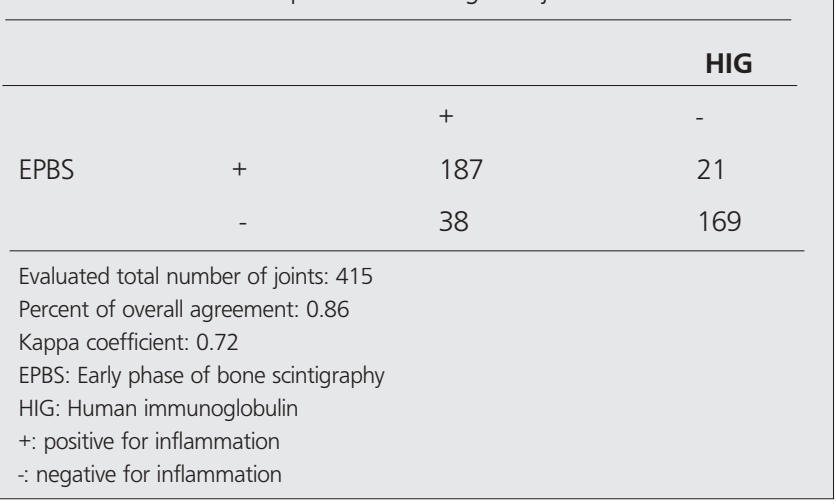

Table 3. The number of joints (showing positive uptake) in terms of severity of arthritis in HIG and EPBS

\begin{tabular}{ccccc}
\hline & & & & HIG \\
\hline \multirow{2}{*}{ EPBS } & 1 & 1 & 2 & 3 \\
& 2 & 29 & & \\
& 3 & & 19 & 40 \\
\hline
\end{tabular}

Evaluated total number of joints: 415 (88/415 joints positive, $327 / 415$ joints negative)

Percent of overall agreement: 0.47

Kappa coefficient: 0.29

EPBS: Early phase of bone scintigraphy

HIG: Human immunoglobulin

1: Faint uptake (mild inflammation)

2: Moderate uptake (moderate inflammation)

3: Marked uptake (severe inflammation)

Table 4. The number of positive and negative joints in HIG and LPBS

\begin{tabular}{llllll}
\hline & & & & HIG \\
\hline \multirow{2}{*}{ LPBS } & & & + & & - \\
& + & 141 & 104 & \\
& $-\quad 10$ & 218 & \\
\hline
\end{tabular}

Evaluated total number of joints: 473

Percent of overall agreement: 0.75

Kappa coefficient: 0.51

LPBS: Late phase of bone scintigraphy

HIG: Human immunoglobulin

+: positive for inflammation

$\therefore$ negative for inflammation determination of the presence of arthritis (percent of overall agreement: 0.86, kappa: 0.72). This means that HIG and EPBS are in agreement in 356 of 415 joints. However, the agreement of HIG and EPBS was poor in the evaluation of the severity of arthritis (percent of overall agreement: 0.47, kappa: 0.29). In another words, only 256 of 415 joints showed good agreement in HIG and EPBS for the determination of the severity of arthritis. Klett et al (30) also showed excellent agreement between HIG and EPBS in the determination of the presence of arthritis but they did not investigate the agreement for the severity of arthritis. In the present study, poor agreement was found between HIG - LPBS in the determination of the presence (kappa: 0.51 ) and severity (kappa: 0.01 ) of inflammatory arthritis. In the literature, there is not any information about the agreement of two modalities for the severity of arthritis. Many studies also indicated that HIG scintigraphy, when compared to bone scintigraphy, is a more specific method to detect synovitis and shows differentiation between different degrees of arthritis acitivity $(2,15,24)$. HIG and MDP are completely different radiopharmaceuticals in terms of uptake mechanisms. Bois et al suggest that two scintigraphic techniques reflect different processes. HIG scintigraphy measures inflammation and bone scintigraphy measures bone turnover. The differences between the results of the two scintigraphic techniques can be explained by the different uptake mechanisms of the radiopharmaceuticals (15). While increased vascular permeability (17), specific trapping of $\lg G$ by receptors for immunoglobulins located on inflammatory cells (18), binding of to extracellular matrix proteins (19) are factors proposed for HIG, only increased vascular permeability and metabolic activity of bone are responsible for EPBS and LPBS, respectively, in inflammatory arthritis (1). Our

Table 5. The number of joints (showing positive uptake) in terms of severity of arthritis in HIG and LPBS

\begin{tabular}{lllll}
\hline & & & & HIG \\
\hline \multirow{2}{*}{ LPBS } & 1 & 1 & 2 & 3 \\
& 2 & 7 & & \\
& 3 & & 6 & 62
\end{tabular}

Evaluated total number of joints: 473 (75/473 joints positive, 402 joints negative) Percent of overall agreement: 0.35

Kappa coefficient: 0.01

LPBS: Late phase of bone scintigraphy

HIG: Human immunoglobulin

1: Faint uptake (mild inflammation)

2: Moderate uptake (moderate inflammation)

3: Marked uptake (severe inflammation) 
results showed that the agreement between HIG - EPBS is better than HIG - LPBS in terms of the determination of the presence and severity of the disease. In the LPBS, the main affected factor of accumulation of tracer is the bony turnover (15). Even after improvement of synovitis, since neighboring bony turnover would still continue, LPBS would show increased tracer accumulation.

The main drawback of the present study is absence of a gold standart test for investigation of synovitis of arthtritic joints. In the present study, patients were diagnosed according to ACR criteria for RA, and clinical-laboratory data for ReA. The histologic examination is the gold standart modality for evaluating synovitis. Because of its invasiveness, there is only one study comparing the results of HIG scintigraphy with histologic examination (23). In this study, false positive as well as false negative results are shown with a higher number of false positive results. However, the present study had addressed to investigate only the agreement between two imaging modalities for the determination of the presence and the severity of the inflamatory arthritis rather than the primary diagnosis.

\section{Conclusion}

Our results showed good agreement between HIG - EPBS for the presence of inflammation but not for the severity of the disease and poor agreement between HIG - LPBS for both the presence and severity of inflammatory arthritis. The blood pool scintigraphy could be used for the investigation of the presence of inflammatory arthritis because of the good agreement with HIG and lower cost but not for the severity of the disease.

\section{References}

1. Bois MHW, Pauwels EKJ. Arthritis: current status of scintigraphy and future trends. In: Murray IPJ, Ell PJ ( eds). Nuclear Medicine in Clinical Diagnosis and Treatment 1st ed. New York: Churchill Livingstone; 1994;1041-1054.

2. Berna L, Torres G, Diez C, Estorch M, Martinez-Duncher D, Carrio I. Technetium-99m human polyclonal immunoglobulin $G$ studies and conventional bone scans to detect active joint inflammation in chronic rheumatoid arthritis. Eur J Nucl Med 1992;19:173-176.

3. Pons F, Moya F, Hernanz R, Sola M, Del Olmo JA, Piera C, MunozGomez J, Setoain J. Detection and quantitative analysis of joint activity inflammation with $99 \mathrm{mTc}$-polyclonal human immunoglobulin $\mathrm{G}$. Nucl Med Commun 1993;14:225-231.

4. Lee KH, Son MK, Ha YJ, Choi ST, Lee SW, Park YB, Lee SK. Inflammatory polyarthritis in a patient with psoriasis: is it psoriatic arthritis or rheumatoid arthritis? Korean J Intern Med 2010;25: 224-226.

5. Tishler M, Lysyy O, Levy O, Volkov O, Golan H. 99m Tc-albumin nanocolloid joint scintigraphy in rheumatoid arthritis patients who are in clinical remission-is remission real? Clin Exp Rheumato 2010;28(3):360-364.
6. Bois MHW, Pauwels EKJ, Breedveld FC. New agents for scintigraphy in rheumatoid arthritis. Eur J Nucl Med 1995;22:1339-1346.

7. Desaulniers $M$, Fuks A, Hawkins $D$, Lacourciere $Y$, Rosenthall $L$. Radiotechnetium polyphosphate joint imaging. J Nucl Med 1974; 15:417-423.

8. Mc carty DJ, Polcyn RE, Collins PA. Technetium $99 \mathrm{~m}$ scintiphotography in arthritis. II. Its nonspecificity and clinical and roentgenographic correlations in rheumatoid arthritis. Arthr Rheum 1970;13:21-32.

9. Helfgott S, Rosenthall L, Esdaile J, Tannenbaum H. Generalize skeletal response to $99 \mathrm{~m}$ technetium methylene diphosphonate in rheumatoid arthritis. J Rheumatol 1982;9:939-941.

10. McCall IW, Sheppard H, Haddaway M, Park W M, Ward DJ. Gallium 67 scanning in rheumatoid arthritis. $\mathrm{Br} \mathrm{J}$ Radiol 1983;56:241-243

11. Colleman RE, Samuelson CO, Baim S, Christian PE, Ward JR. Imaging with Tc-99m MDP and Ga-67 citrate in patients with rheumatoid arthritis and suspected septic arthritis (concise communication). J Nucl Med 1982;23:479-482.

12. Liberatore $M$, Clemente $M$, lurilli $A P$, Zorzin L, Marini $M$, Di Rocco $E$, Colella AC. Scintigraphic evaluation of disease activity in rheumatoid arthritis: a comparison of technetium- $99 \mathrm{~m}$ human non-specific immunoglobulins, leucocytes and albumin nanocolloids. Eur J Nucl Med 1992;19:853-857.

13. De Sousa M, Bastos AL, Dynesius-Trentham R, Kerr S, Bernardo A, Duarte JG, Trentham DE. Potential of indium-111 to measure inflammatory arthritis. J Rheumatol 1986;13:1 108-1116.

14. O'Sullivan MM, Powell N, French AP, Williams KE, Morgan JR, Williams BD. Inflammatory joint disease: a comparison of liposome scanning, bone scanning, and radiography. Ann Rheum Dis 1988:47:485-491.

15. Bois de MHW, Arndt JW, Velde van der EA, Pauwels EKJ, Breedveld FC. Joint scintigraphy for quantification of synovitis with $99 \mathrm{mTc}$ labelled human immunoglobulin $\mathrm{G}$ compared to late phase scintigraphy with $99 \mathrm{~m}$-labelled disphosphonate. $\mathrm{Br} J$ Rheumatol 1994:33:67-73.

16. Chaudhari AJ, Bowen SL, Burkett GW, Packard NJ, Godinez F, Joshi AA, Naguwa SM, Shelton DK, Hunter JC, Boone JM, Buonocore MH, Badawi RD. High-resolution (18)F-FDG PET with MRI for monitoring response to treatment in rheumatoid arthritis. Eur J Nucl Med Mol lmaging 2010;37:1047-1047.

17. Morrell EM, Tompkins RG, Fischman AJ, Wilkinson RA, Burke JF, Rubin RH, Strauss HW, Yarmush ML. Autoradiographic method for quantitation of radiolabeled proteins in tissues using indium-111. J Nucl Med 1989:30:1538-1545.

18. Rubin RH, Fischman AJ, Callahan RJ, Khaw BA, Keech F, Ahmad M, Wilkinson R, Strauss HW. Ind-111-labeled nonspecific immunoglobülin scanning in defection of focal infection. $N$ Engl J Med 1989;321:935-940.

19. de Bois $M H$, Welling $M$, Verwey $C L$, de Vries $E$, Pauwels EK, Breedveld FC, Tak PP. Tc99m-HIG accumulation in sinovial tissue of rats with adjuvant arthritis by binding to extracellular matrix proteins. Nucl Med Commun 1996; 17:54-59.

20. Güngör F, Karayalcın B, Gültekin M, Paksoy N, Sentürk UK, Kaputlu I, Yildiz A, Erkiliç M. Comparison of Tc-99m HIG and Ga-67 citrate in evaluation of bacterial abscess in a rat model. Ann Nuc Med 1996; 10:79-83

21. Fuchs HA, Sergent JS. Rheumatoid Arthritis: The clinical picture. In W J Koopman (ed). Arthritis and allied conditions. Baltimore: Williams and Wilkins; 1997;1041-1070.

22. Bloch DA, Kraemer HC. 232 Kappa coefficients: Measures of agreement or association. Biometrics 1989;269-287.

23. Bois de MHW, Tak PP, Arndt JW, Kluin PM, Pauwels EKJ, Breedveld FC. Joint scintigraphy for quantification of synovitis with $99 \mathrm{mTc}$ labelled human immunoglobulin $\mathrm{G}$ compared to histological examination. Clin Exp Rheumatol 1995;13:155-159. 
24. Kadanali A, Varoglu E, Kerek M, Tasyaran MA. Tc99m polyclonal human immunoglobuline scintigraphy in brucellosis. Clin Microbiol Infect 2005;1 1:480-485.

25. Jamar $F$, Manicourt DH, Leners $N$, van den Berghe $M$, Beckers $C$. Evaluation of disease activity in rheumatoid arthritis and other arthritides using technetium- $99 \mathrm{~m}$ labelled nonspecific human immunoglobulin. J Rheumatol 1995;22:850-854.

26. Lubbe van der PAHM, Arndt JW, Calame W, Ferreira TC, Pauwels EKJ, Breedveld FC. Measurement of synovial inflammation in rheumatoid arthritis with technetium- $99 \mathrm{~m}$-labelled human polyclonal immunoglobulin G. Eur J Nucl Med 1991;18:119-123.

27. de Bois MH, Arndt JW, van der Velde EA, van der Lubbe PA, Westedt ML, Pauwels EK, Breedveld FC. Tc $99 \mathrm{~m}$ human immunoglobülin scintigraphy - a reliable method to detect joint activity in rheumatoid arthritis. J Rheumatol 1992;13:1371-1376.
28. de Bois MH, Westedt ML, Arndt JW, Wiarda KS, van der Velde EA, Pauwels EK, Breedveld FC. Technetium-99m labelled polyclonal human immunoglobulin $G$ scintigraphy before and 26 weeks after initiation of patenteral gold treatment in patients with rheumatoid arthritis. J Rheumatol 1995;22:1461-1465.

29. Sahin M, Bernay I, Basoglu T, Canturk F. Comparison of Tc-99m MDP, Tc-99m HSA and Tc-99m HIG uptake in rheumatoid arthritis and its variants. Ann Nucl Med 1999;13:389-395.

30. Klett R, Grau K, Puille M, Matter HP, Lange U, Steiner D, Baver R. Comparison of HIG scintigraphy and bloodpool scintigraphy using HDP in arthritic joint disease. Nuklearmedizin 2000;39:33-37. 